\title{
Research into Problems in China's Criminal Law Education
}

\author{
Chen Di, Wei Fang \\ Jiangxi University of Technology
}

\begin{abstract}
Criminal is an important legal course, and its teaching method is especially important. Teaching is a process combines teachers' teaching and students' learning together, both of which are indispensable. The concept of teaching reflects people's collective understanding of teaching and learning activities' internal rules; and meanwhile it is people's basic attitude and view on teaching activities. Therefore, the teaching concept of criminal law mainly reflects on teachers' teaching concept and students' learning concept. In this paper, according to the curriculum features of criminal law, it explains problems of teachers and students existing in current of criminal law teaching with proposal of some countermeasures.
\end{abstract}

Keywords-criminal law; education; countermeasure; feature

\section{INTRODUCTION}

Generally, system of criminal law is a structure formed by arrangement and organization of contents by specifying the research objects of criminal law. Study and mastery of criminal law system indicate the knowledge about the integrity of criminal law as well as its relations, which is an important condition for further development of criminal law. In other word, system of criminal law is a combination of knowledge formally, but it is an analysis mode, logic structure and thinking mode essentially. In the past, we only pay attention to the superficial form with little importance to its essence, which results in a super-stable status. The purpose of reflecting on traditional criminal law system is to discover problems and to rebuild a new system.

Since the study on jurisprudence is becoming deeper and prosperous, educators on criminal law teaching have constantly made revolutions and innovations on teaching methods. Especially after implementation of national judicial examination, more attention has been paid to the combination of theories and practice, which has achieved better educational effect. However, affected by traditional concept, contents and methods, teaching of criminal law still have some problems needing to be solved. In this paper, the author explains the curriculum features of criminal law as well as main existing problems in criminal law teaching with proposal of countermeasures.

\section{CHARACTERISTICS OF THE COURSES OF CRIMINAL} LAW

The research objects of criminal law are complicated. Theory of criminal law, crime theory and liabilities of criminal law are three parts of the general knowledge system of criminal law. Apart from general theory of criminal law, there is also dispersed theory of criminal law, which mainly prescribes the concept, features, boundaries of different crimes as well as affirmation of different crimes. Thus, the course of criminal law not only simply explains the legal theories, but it also integrates criminal law, criminal philosophy, criminal law explanations as well as adaptable rules, experience and trials all together.

It involves wide and extensive contents. The contents of criminal law are very broad. Social relations involved by criminal law include personal safety, family safety, financial safety, economic safety, social orders, public safety and national safety and so on. The concrete contents cover national regime safety, territory safety, public transportation safety, food and drug safety, production and operation safety as well as finance, tax, customs, health, property and professional integrity and so on. Therefore, common contents needing to be protected and covered by general departments are all covered by criminal law with protection. Therefore, criminal law is also called "secondary protection law". 
It has a close relationship with practice. Criminal law is a discipline with strong theoretical property and application. Crimes covered by criminal law and the basic principles of criminal liabilities have both deep philosophical property and rich practicability. Criminal law originates from criminal legal theories, criminal legislation and criminal justice practice, and in turn, it serves criminal legislation and justice practice. Teaching of criminal law aims to guide national criminal legislation, improve national criminal justice and perfect the basic theories of criminal law by studying and researching theories of criminal law.

\section{EXISTING PROBLEMS OF THE TEACHING METHODS} FOR CRIMINAL LAW

\section{A. The pure purpose of teaching criminal law}

In the teaching of criminal law in China, some teachers still insist on professional teaching concepts with little importance to the relationship between criminal law and other disciplines. For example, when teaching criminal law knowledge, some teachers may leave the problems to teachers of other disciplines without detailed explanation. Criminal law is a humanistic discipline. In order to master its basic principles and basic thoughts, teachers need to master rich knowledge and sound qualities in the first place.

\section{B. Students' learning effect is evaluated by their written result}

Quality of teaching is the essence for teachers' survival as well as the basis for school's development. At present, most colleges and universities evaluate students' learning result by their daily performance as well as final results, which account for $30 \%$ and $70 \%$ respectively. Based on traditional teaching concept, teaching of criminal law also evaluates students' learning effect by their results. Thus, students pay much attention to knowledge memorizing without active thinking or effective communications among teachers. Besides, there is little doubt of controversial criminal law knowledge, which can affect the cultivation of students' innovative capability.

\section{Students' learning are passive}

Usually criminal law courses are set up in the second term of the freshman year or the senior year in colleges and universities. However, students during this period have less initiative after high-school mechanical study mode. Therefore, they can be adaptable to the indoctrinated teaching method. Students are used to taking notes in class, but they don't dare doubt or propose their own thoughts.

\section{SUGGESTIONS TO CRIMINAL LAW TEACHING}

\section{A. Class teaching}

In terms of teaching contents, teaching outline has always seen as the basis for criminal law teaching with great importance to its basic concepts, basic knowledge and basic theories. Besides, relevant contents have been added to several criminal legislation interpretation and criminal amendments with timely modification and complement so that teaching contents have been combined with the development of criminal law in China. On this basis, new topics, new ideas and new theories in criminal fields should be introduced to class teaching appropriately so that students can know about the latest development of criminal law.

\section{B. Case discussion}

Case discussion is an indispensable section of criminal law teaching, which can help to cultivate students' ability of applying legal knowledge to analyze problems. Some western legal education is conducted by case discussion. The case selected for discussion should be proper, typical and successful. The case should not be too easy or too complicated, or it will be difficult for beginners to study. Besides, the scale should be controlled since large class teaching is not beneficial to class teaching, and it can also affect the atmosphere of class discussion by offering many opportunities to students.

\section{Theoretical seminar}

Although criminal law is a relatively mature discipline, there are still many theoretical and practical problems needing to be solved. As for the beginners of criminal law, it is not realistic for students to understand the deep theoretical studies at once, they should be 
guided to provide basis for future development. Students can be guided to write down some academic opinions and short thesis on criminal law difficulties according to the teaching procedure by making students read more books and articles with strong ability of discovering and researching problems. By reading and literature review, students' capability of collecting, arranging and digesting materials can be exercised.

\section{CONCLUSION}

Problems existing in criminal law teaching are not formed in one day, so these problems can't be solved immediately, while corresponding measures and countermeasures should be taken urgently to improve the backward teaching of criminal law. By analyzing problems existing in the teaching of criminal law as well as the reasons, we can find rational ways to cultivate criminal talents in criminal law teaching, which shall be carried out urgently. In this paper, three suggestions have been proposed for the problems above. First, theories taught in class should be improved; second, theoretical interactions in class should be enhanced; finally, case study in class should be advocated. With the help of these teaching methods, students' activeness can be mobilized so that they can have a better study.

\section{REFERENCES}

[1] Schnur A C. The New Penology: Fact or Fiction?[J]. Journal of Criminal Law \& Criminology, 1958, 49(4):331-334.

[2] Willis J J, Mastrofski S D. Compstat and The New Penology[J]. British Journal of Criminology, 2012, volume 52(1):73-92(20).

[3] Thorne F C, Forgays D G. Mission impossible: The ideological conflicts underlying modern penology[J]. Journal of Community Psychology, 1973, 1(3):271-277.

[4] Jenkins P. Temperance and the origins of the new penology[J]. Journal of Criminal Justice, 1984, 12(6):551-565.

[5] William B. Taylor PhD, Michael C. Braswell PhD. REFLECTIONS ON PENOLOGY:[J]. Journal of Offender Counseling Services Rehabilitation, 1980, 4(2):109-120.

[6] Jensen H E. Criminology and Penology[J]. Social Forces, 1939, 18(2):289-291.

[7] Brisson L. Penology and Eschatology in Plato's Myths (review)[J]. Journal of the History of Philosophy, 2003, 41:410-411.

[8] Tabasz T F. Penology, economics, and the public: Toward an agreement[J]. Policy Sciences, 1974, 5(1):47-55.

[9] Killinger, George Glenn, P. F. Cromwell, and J. M. Wood. Penology : the evolution of corrections in America. West Pub. Co., 1973.

[10] Odeshoo, Jason R. "Of Penology and Perversity: The Use of Penile Plethysmography on Convicted Child Sex Offenders." Temp.pol. \& Civ.rts.1.rev (2004).

[11] Mckelvey, Blake. "Penology in the Westward Movement." Pacific Historical Review 2.4(1933):418-438.

[12] FRANCES B. SINGH. (2003). Antigone's changed punishment: gynaecology as penology in sophocles' antigone. Australian Feminist Studies, 18(40), 7-16. 